\title{
Health status of school age children employed in carpet weaving in Ganderbal Block
}

\author{
G M MATTOO, ${ }^{1}$ A RAUF, ${ }^{2}$ M L ZUTSHI \\ From the Department of Community Medicine, ${ }^{1}$ Institute of Medical Sciences, and Departments of Social \\ and Preventive Medicine, ${ }^{2}$ and Statistics, ${ }^{3}$ Government Medical College, Srinagar, Kashmir
}

ABSTRACT In a health and morbidity screening among 500 carpet weaving children and 450 children attending school selected at random in a rural field practice area the age group studied was from 6 to 16. Each child was thoroughly interviewed and examined for any deviation from health. The height and weight were taken by standard procedures and clinical assessment of morbidity and nutritional status was also observed. The results showed that the heights and weights of schoolchildren were greater than those of the carpet weaving children in both boys and girls. Clinically, $56 \%$ of the schoolchildren as against $41.6 \%$ of carpet weaving children had no nutritional defects. The main complaints in the carpet weaving children were in order of descent, headache, blurring of vision, backache, abdominal pain, limb pains, and respiratory tract infection. Both groups of children were later followed up for six months from September 1981 to March 1982. The incidence of subjective and objective deviations from health were higher in the carpet weaving than in the schoolchildren and the first ten major complaints in the carpet weaving children were respiratory $\vec{\oplus}$ tract infection, headache, backache, pain in the abdomen, injuries (major and minor), joint pain 8 diarrhoea and dysentery, fever of unknown origin, dermatitis, and chilblains.

The health status of children (6-16 years) engaged in carpet weaving in a rural area of Kashmir was compared with that of children attending school in the same area. A cross sectional study was conducted in the Ganderbal Block at a distance of $30 \mathrm{~km}$ from the Srinagar Medical College and a longitudinal morbidity study was conducted in the same place and on the same children from September 1981 to March 1982. A random sample of 500 school age children was selected from the carpet weaving group and another sample of 450 children was selected at random from the schools in the same area to act as a control group.

Because of the overall problem of poverty the children in Kashmir are made to work in the weaving centres at an early age, despite restrictions under the Indian Factories Act. This being a tender age in the context of repercussions on health due to the postural and exhaustive working conditions, a study of this type was thought desirable as no such study had been attempted in the past in this part of the country.

Accepted 21 April 1986

\section{Material and methods}

The 83 carpet weaving centres in Ganderbal Block were serially listed and every fifth centre was selected and all the workers aged from 6 to 16 were taken for study. Those children having less than six months exposure were withdrawn from the study: 450 children attending school in the same age group were selected at random from eight schools in the area. Each child was thoroughly interviewed and examined and whenever possible additional information was obtained from the parents of the child. The schedule was made and pretested. The anthropometric measurements were taken by standard methods as recommended by Jellife. $^{1}$ The morbidity evaluation was based on history, general physical examination, and systemic $\mathcal{N}$ examination supported by clinical investigations. Each child was visited every 15 days during the longitudinal study period of six months and all the deviations from health, subjective or objective, were recorded for the last 15 days and any sickness occurring within the period of 15 days was recorded as one spell of sickness. 
Health status of school age children employed in carpet weaving in Ganderbal Block

Table $1($ a) Average height $(\mathrm{cm})$

\begin{tabular}{|c|c|c|c|c|c|c|c|c|}
\hline \multirow[b]{3}{*}{$\begin{array}{l}\text { Age } \\
\text { (years) }\end{array}$} & \multicolumn{4}{|l|}{ Boys } & \multicolumn{4}{|l|}{ Girls } \\
\hline & \multicolumn{2}{|c|}{ Carpet industry } & \multicolumn{2}{|l|}{ School } & \multicolumn{2}{|c|}{ Carpet industry } & \multicolumn{2}{|l|}{ School } \\
\hline & $\begin{array}{l}\text { Average } \\
\text { height }\end{array}$ & $\begin{array}{l}\text { Growth } \\
\text { rate (\% age) }\end{array}$ & $\begin{array}{l}\text { Average } \\
\text { height }\end{array}$ & $\begin{array}{l}\text { Growth } \\
\text { rate (\% age) }\end{array}$ & $\begin{array}{l}\text { Average } \\
\text { height }\end{array}$ & $\begin{array}{l}\text { Growth } \\
\text { rate (\% age) }\end{array}$ & $\begin{array}{l}\text { Average } \\
\text { height }\end{array}$ & $\begin{array}{l}\text { Growth } \\
\text { rate (\% age) }\end{array}$ \\
\hline 6 & - & - & - & - & 104.9 & - & $105 \cdot 5$ & - \\
\hline 7 & 115.4 & - & 114.2 & - & $109 \cdot 3$ & $4 \cdot 2$ & $108 \cdot 8$ & $3 \cdot 1$ \\
\hline 8 & 119.6 & 4.5 & 118.4 & $3 \cdot 7$ & 113.7 & $4 \cdot 0$ & 114.8 & $5 \cdot 5$ \\
\hline 9 & $124 \cdot 2$ & $3 \cdot 8$ & 123.6 & 4.4 & 119.6 & $5 \cdot 2$ & $121 \cdot 2$ & $5 \cdot 6$ \\
\hline 10 & 129.8 & 4.5 & 129.6 & 4.9 & $125 \cdot 3$ & 4.8 & $126 \cdot 1$ & $4 \cdot 0$ \\
\hline 11 & 133.6 & 2.9 & 135.8 & 4.8 & 132.4 & 5.7 & $131 \cdot 5$ & $4 \cdot 3$ \\
\hline 12 & 137.6 & 3.0 & $140 \cdot 3$ & $3 \cdot 3$ & 137.7 & 4.0 & $136 \cdot 3$ & 3.7 \\
\hline 13 & $142 \cdot 3$ & 3.4 & $145 \cdot 2$ & $3 \cdot 5$ & 142.4 & 3.4 & 142.5 & $4 \cdot 5$ \\
\hline 14 & 146.8 & $3 \cdot 2$ & 150.8 & 3.9 & 146.8 & $3 \cdot 1$ & 146.5 & $2 \cdot 8$ \\
\hline 15 & 150.9 & 2.8 & 154.6 & $2 \cdot 5$ & $150 \cdot 5$ & $2 \cdot 5$ & 151.4 & $3 \cdot 3$ \\
\hline 16 & 154.6 & $2 \cdot 5$ & 159.4 & $3 \cdot 1$ & 151.2 & 0.5 & 152.5 & 0.7 \\
\hline
\end{tabular}

Table $1(b)$ Analysis of variance

\begin{tabular}{|c|c|c|c|c|c|c|c|c|c|c|}
\hline \multirow{2}{*}{$\begin{array}{l}\text { Sources of } \\
\text { variation }\end{array}$} & \multicolumn{5}{|c|}{ Boys } & \multicolumn{5}{|c|}{ Girls } \\
\hline & $D F$ & $S S$ & $M S$ & $F$ & $p$ & $D F$ & $S S$ & $M S$ & $F$ & $p$ \\
\hline $\begin{array}{l}\text { Due to age } \\
\text { Type of activity } \\
\text { Error } \\
\text { Total }\end{array}$ & $\begin{array}{r}9 \\
1 \\
9 \\
19\end{array}$ & $\begin{array}{r}3858 \cdot 55 \\
14.62 \\
23.66 \\
3796.83\end{array}$ & $\begin{array}{r}417.62 \\
14.62 \\
2.63\end{array}$ & $\begin{array}{r}158 \cdot 79 \\
5 \cdot 56\end{array}$ & $\begin{array}{l}<0.001 \\
<0.05\end{array}$ & $\begin{array}{r}10 \\
1 \\
11 \\
21\end{array}$ & $\begin{array}{r}5622 \cdot 61 \\
0 \cdot 49 \\
4 \cdot 71 \\
5627 \cdot 81\end{array}$ & $\begin{array}{c}562 \cdot 26 \\
0.49 \\
0.428\end{array}$ & $\begin{array}{r}1313.69 \\
1 \cdot 14\end{array}$ & $\begin{array}{l}<0.01 \\
>0.05\end{array}$ \\
\hline
\end{tabular}

Table $2(a)$ Average weight ( $k g$ )

\begin{tabular}{|c|c|c|c|c|}
\hline \multirow[b]{2}{*}{ Age (years) } & \multicolumn{2}{|l|}{ Boys } & \multicolumn{2}{|l|}{ Girls } \\
\hline & Carpet industry & School & Carpet industry & School \\
\hline $\begin{array}{r}6 \\
7 \\
8 \\
9 \\
10 \\
11 \\
12 \\
13 \\
14 \\
15 \\
16\end{array}$ & $\begin{array}{l}\overline{17} \cdot 8 \\
20 \cdot 2 \\
22 \cdot 4 \\
24 \cdot 2 \\
27 \cdot 4 \\
29 \cdot 3 \\
31 \cdot 3 \\
34 \cdot 1 \\
38 \cdot 2 \\
41 \cdot 2\end{array}$ & $\begin{array}{l}\overline{18} \cdot 0 \\
20 \cdot 2 \\
22.8 \\
25.4 \\
28.6 \\
30.9 \\
36 \cdot 0 \\
39.7 \\
41.9 \\
44.1\end{array}$ & $\begin{array}{l}14 \cdot 0 \\
15 \cdot 5 \\
17 \cdot 3 \\
20 \cdot 2 \\
23 \cdot 0 \\
25 \cdot 4 \\
27 \cdot 6 \\
31 \cdot 1 \\
35 \cdot 7 \\
40 \cdot 3 \\
42.4\end{array}$ & $\begin{array}{l}15 \cdot 1 \\
16 \cdot 4 \\
18 \cdot 9 \\
21 \cdot 6 \\
23 \cdot 1 \\
25 \cdot 7 \\
28 \cdot 0 \\
32 \cdot 2 \\
35 \cdot 3 \\
40 \cdot 6 \\
44 \cdot 0\end{array}$ \\
\hline
\end{tabular}

Table 2(b) Analysis of variance

\begin{tabular}{|c|c|c|c|c|c|c|c|c|}
\hline \multirow{2}{*}{$\begin{array}{l}\text { Sources of } \\
\text { variation }\end{array}$} & \multicolumn{4}{|c|}{ Boys } & \multicolumn{4}{|c|}{ Girls } \\
\hline & $D F$ & $s S$ & $M S$ & $\boldsymbol{F}$ & $D F$ & $S S$ & $M S$ & $F$ \\
\hline $\begin{array}{l}\text { Type of activity } \\
\text { Error } \\
\text { Total }\end{array}$ & $\begin{array}{r}1 \\
18 \\
19\end{array}$ & $\begin{array}{l}23.117 \\
1315.933 \\
1339.05 \\
p>0.05\end{array}$ & $\begin{array}{l}23 \cdot 117 \\
73 \cdot 10 \\
\text { ignifican }\end{array}$ & 0.31 & $\begin{array}{r}1 \\
20 \\
21\end{array}$ & $\begin{array}{r}3.21 \\
1900.36 \\
1903.57 \\
p>0.05\end{array}$ & $\begin{array}{r}3.21 \\
95.01 \\
\text { ignific: }\end{array}$ & 0.03 \\
\hline
\end{tabular}


Table 3 Distribution of children by clinical assessment of nutritional status

\begin{tabular}{|c|c|c|c|c|c|}
\hline \multirow{2}{*}{$\begin{array}{l}\text { Nutritional } \\
\text { status }\end{array}$} & \multirow{2}{*}{$\begin{array}{l}\text { Nutritional defects } \\
\text { detected }\end{array}$} & \multicolumn{2}{|c|}{ Carpet weaving children } & \multicolumn{2}{|c|}{ Schoolchildren } \\
\hline & & No & $\%$ & $N o$ & $\%$ \\
\hline \multirow{8}{*}{$\begin{array}{l}\text { I Normal } \\
\text { II Abnormal }\end{array}$} & No defects & 208 & $41 \cdot 60$ & 252 & $56 \cdot 00^{*}$ \\
\hline & $\begin{array}{l}\text { Pale conjunctiva } \\
\text { Mouth }\end{array}$ & 288 & $57 \cdot 60$ & 185 & $41 \cdot 00^{*}$ \\
\hline & $\begin{array}{l}\text { Angular stomatitis } \\
\text { Hair }\end{array}$ & 187 & $37 \cdot 40$ & 54 & $12 \cdot 00^{*}$ \\
\hline & $\begin{array}{l}\text { Lack of lustre } \\
\text { Tongue }\end{array}$ & 27 & $5 \cdot 40$ & 9 & $2 \cdot 00$ \\
\hline & $\begin{array}{l}\text { Atrophic papillae } \\
\text { Nails }\end{array}$ & 23 & $4 \cdot 60$ & 18 & 4.00 \\
\hline & $\begin{array}{l}\text { Platynychia } \\
\text { Skin }\end{array}$ & 18 & 3.60 & 0 & 0.00 \\
\hline & $\begin{array}{l}\text { Dry } \\
\text { Gums }\end{array}$ & 13 & $2 \cdot 60$ & 5 & $1 \cdot 11$ \\
\hline & Spongy and bleeding & 11 & $2 \cdot 20$ & - & - \\
\hline
\end{tabular}

One child may be represented more than once.

*Statistically significant at the $5 \%$ level.

\section{Observations}

\section{ANTHROPOMETRY TABLES}

Height-The height of the carpet weaving children, both girls and boys, was overall less than that of the controls. There was a retarding tendency in the rate of growth (development), especially in the boys. The analysis of variance test applied on average estimates also depicts a significant departure at $\mathrm{p}<0.05$ as shown in tables $1(a)$ and $(b)$.

Weight-Regarding weight estimates no such tendency was observed despite the fact that higher weights were observed among the control children as shown in tables $2(a)$ and $(b)$.

Nutritional status - The clinical assessment of nutritional status (table 3 ) showed that $41.6 \%$ of the carpet weaving children had no sign of nutritional deficiency as against $56 \%$ of the control children. This difference was found to be statistically significant at the $5 \%$ level.

Conjunctival pallor was the most common sign of nutritional deficiency seen in both groups of children, $\infty$ being present in $57.6 \%$ of the carpet weaving children and $41 \%$ of the controls. Similarly, angular stomatitis was observed in $37.4 \%$ of the carpet weaving children but in only $12 \%$ of the schoolchildren.This difference was statistically significant at the $5 \%$ level. Other signs such as lack of lustre in hair and atrophic papillae on the tongue were also found in both groups but more often in the carpet weaving than the contre children.

The prevalence of presenting complaints in the cross sectional study (table 4) showed that headache, blurring of vision, backache, abdominal pain, limb pains, and respiratory tract infection were the major complaints and the prevalence rate of these diseases differed significantly between the two groups $(p<0.05)$.

While reviewing the period of exposure, it has been observed that vision, headache, and limb pain were experienced comparatively much earlier than backache and respiratory tract infection. Whereas in the

Table 4 Children by presenting complaints and exposure to the activity

\begin{tabular}{|c|c|c|c|c|}
\hline \multirow[b]{2}{*}{ Present complaints } & \multicolumn{2}{|c|}{ Carpet weaving children } & \multicolumn{2}{|c|}{ Schoolchildren } \\
\hline & $\begin{array}{l}\text { Prevalence } \\
\text { rate }\end{array}$ & $\begin{array}{l}\text { Average period of } \\
\text { exposure (years) }\end{array}$ & $\begin{array}{l}\text { Prevalence } \\
\text { rate }\end{array}$ & $\begin{array}{l}\text { Average period of } \\
\text { exposure (years) }\end{array}$ \\
\hline $\begin{array}{l}\text { Headache } \\
\text { Blurring of vision } \\
\text { Backache } \\
\text { Pain in abdomen } \\
\text { Limb pains } \\
\text { Respiratory tract infection } \\
\text { All types }\end{array}$ & $\begin{array}{l}28 \cdot 8 \\
23 \cdot 4 \\
21 \cdot 6 \\
14 \cdot 2 \\
8 \cdot 4 \\
11 \cdot 8 \\
58 \cdot 00\end{array}$ & $\begin{array}{l}2 \cdot 1 \\
2 \cdot 9 \\
6 \cdot 1 \\
3 \cdot 2 \\
2 \cdot 2 \\
5 \cdot 4 \\
3 \cdot 6\end{array}$ & $\begin{array}{r}8 \cdot 00 \\
4 \cdot 00 \\
1.00 \\
12 \cdot 00 \\
8 \cdot 00 \\
5 \cdot 00 \\
35 \cdot 00\end{array}$ & $\begin{array}{l}7 \cdot 3 \\
7 \cdot 3 \\
8 \cdot 7 \\
4 \cdot 4 \\
1 \cdot 6 \\
1 \cdot 9 \\
4 \cdot 3\end{array}$ \\
\hline
\end{tabular}

One child may be represented more than once. 
Table 5 Carpet weaving children by number of defects and period of exposure

\begin{tabular}{|c|c|c|c|c|c|c|}
\hline \multirow[b]{2}{*}{ Period of exposure (years) } & \multicolumn{6}{|c|}{ No of defects } \\
\hline & 0 & 1 & 2 & 3 & $\geqslant 4$ & Total \\
\hline $\begin{array}{c}-2 \\
2-3 \\
3-4 \\
4-5 \\
5-6 \\
\geqslant 6 \\
\text { Total }\end{array}$ & $\begin{array}{r}23 \\
24 \\
18 \\
15 \\
9 \\
7 \\
96\end{array}$ & $\begin{array}{r}28 \\
48 \\
36 \\
20 \\
8 \\
6 \\
146\end{array}$ & $\begin{array}{r}14 \\
36 \\
32 \\
26 \\
15 \\
13 \\
136\end{array}$ & $\begin{array}{r}2 \\
12 \\
17 \\
23 \\
14 \\
14 \\
82\end{array}$ & $\begin{array}{r}0 \\
3 \\
7 \\
18 \\
7 \\
5 \\
40\end{array}$ & $\begin{array}{r}67 \\
123 \\
110 \\
102 \\
53 \\
45 \\
500\end{array}$ \\
\hline
\end{tabular}

schoolchildren defects of vision and headache occurred after a mean time at school of 4.3 years, in the carpet weaving children such complaints affected them on average 3.6 years after they started work. The carpet weaving children were further analysed by period of exposure and number of physical defects (table 5). The average period of exposure was 3.67 \pm 1.48 years against an average number of defects of $1.61 \pm 1.32$.The analysis showed an increasing number of defects with an increase in the duration of exposure. The relation between the factors was statistically significant with a positive co-relation $(r=+0.36)$.

\section{Personal hygiene}

Personal hygiene was unsatisfactory in both groups; whereas satisfactory hygiene in the schoolchildren varied from $5 \%$ to $9 \%$ of children, in the carpet weaving group it varied from $0 \cdot 2 \%$ to $3 \%$.

When the results of the longitudinal morbidity study were analysed, it was found that the first ten causes of morbidity among both groups of children were: respiratory tract infection, headache, backache, abdominal pain, injuries (minor and major), joint pains, diarrhoea and dysentery, fever of unknown origin, dermatitis, and chilblains (table 6). A higher incidence was found in the carpet weaving children for headache, backache, injuries, and joint pains; in the schoolchildren a higher incidence was found for headache, diarrhoea, and dysentery. The preponderance of backache, joint pains, and headache in the carpet weaving children may be attributed to the working conditions such as squatting on the floor, stooping, and constant gazing at their work for long periods. The increase in respiratory tract infection in both groups is because this survey was conducted during the winter months when respiratory tract infection is on the increase owing to the dry cold weather in Kashmir.

The abdominal pain found in both groups is due to the high prevalence of worm infestations which has been observed in many studies and is attributed to bad personal and environmental hygiene. The high incidence of headache and defects in vision, as shown in this survey, could be attributed to a lack of proper illumination in the carpet weaving centres and schools in the rural areas of Kashmir. Most are located in Katchha and are ill ventilated and badly illuminated rooms in mud buildings.

The slightly higher incidence of diarrhoea and dysentery in the schoolchildren is due to the intake of unhygienic food sold outside the schools by hawkers to whom the carpet weaving children have no access; the higher incidence of injuries in the carpet weaving children is attributed to their using sharp instruments in their work.

\section{References}

1 Jellife D. B. The assessment of the nutritional status of the community. Geneva: World Health Organisation, 1966: 50-69, 76-8. (WHO monograph series No 53.)

Table 6 Percentage incidence of first ten major diseases by spells of sickness

\begin{tabular}{|c|c|c|c|c|}
\hline \multirow[b]{2}{*}{ Illness pattern } & \multicolumn{2}{|l|}{ Total spells of sickness } & \multicolumn{2}{|l|}{ Incidence (\%) } \\
\hline & Carpet weaving children & Schoolchildren & Carpet weaving children & Schoolchildren \\
\hline $\begin{array}{l}\text { Respiratory tract infection } \\
\text { Headache } \\
\text { Backache } \\
\text { Pain in abdomen } \\
\text { Injury/minor and major } \\
\text { Joint pains } \\
\text { Diarrhoea and dysentery } \\
\text { Fever of unknown origin } \\
\text { Dermatitis } \\
\text { Chilblains }\end{array}$ & $\begin{array}{r}126 \\
118 \\
107 \\
103 \\
92 \\
73 \\
49 \\
39 \\
34 \\
25\end{array}$ & $\begin{array}{l}75 \\
62 \\
21 \\
95 \\
46 \\
25 \\
58 \\
37 \\
21 \\
33\end{array}$ & $\begin{array}{r}25 \cdot 20 \\
23 \cdot 60 \\
21 \cdot 40 \\
20 \cdot 60 \\
18 \cdot 44 \\
14 \cdot 60 \\
9 \cdot 80 \\
7 \cdot 80 \\
6 \cdot 80 \\
5 \cdot 00\end{array}$ & $\begin{array}{l}18 \cdot 29 \\
15 \cdot 12 \\
5 \cdot 12 \\
23 \cdot 17 \\
11 \cdot 22 \\
6 \cdot 097 \\
14 \cdot 15 \\
90 \cdot 2 \\
5 \cdot 12 \\
8 \cdot 05\end{array}$ \\
\hline
\end{tabular}

